\title{
El Nino/La Nina and IOD impact on Kharif Season Crops Over Western Agro-Climatic Zones of India
}

R. BHATLA ( $\square$ rbhatla@bhu.ac.in )

Banaras Hindu University

S. Bhattacharyya

Banaras Hindu University

Shruti Verma

Banaras Hindu University

R. K. Mall

Banaras Hindu University

R. S. Singh

Dr. Rammanohar Lohia Avadh University

\section{Research Article}

Keywords: ENSO, IOD, Teleconnections, Kharif crop

Posted Date: November 10th, 2021

DOI: https://doi.org/10.21203/rs.3.rs-1057177/v1

License: (c) (1) This work is licensed under a Creative Commons Attribution 4.0 International License. Read Full License 


\section{Abstract}

Climate modes like ENSO (EI Nino Southern Oscillation) and IOD (Indian Ocean Dipole) produce an impact on the monsoon rainfall over India. Monsoon rainfall is extremely important for the agriculture of our country. The impact of these climate modes on monsoon rainfall thus in turn affects the rain-fed crops (Kharif). In this study, four Kharif season crops namely Rice (Oryzasativa), Maize (Zea mays), pulses and sugarcane (Saccharum officinarum) are chosen over four arid/semi-arid agro-climatic zones of western India to study the effect of the climate modes on selected crops. The detailed analysis has been carried out to show the impact of El Nino/La Nina (phases of ENSO) and IOD years on the crop productions over the mentioned zones viz. (Central plateau \& hills region; Western plateau \& hills region; Gujarat hills and plains region; Western Dry region) from 1966-2011. Rice production has been largely affected during drought years associated with El-Nino. The production of Pulses shows marginal improvement during the neutral years or non-El Nino/non-La Nina. The Maize production seems to be better in La Nina years as compared to neutral years and worst in the El Nino years. El Nino years provides a minor impact on Sugarcane productions in different zones. La Nina years are well suited for sugarcane production in any zones of our study. Positive IOD years are associated with poor crop productions as compared to negative IOD years mostly in all zones due to the co-occurrence of positive IOD years with El Nino. The correlations between positive IOD and rainfall are much weaker as compared to the correlations between the El Nino and rainfall in the years of co-occurrences over the zones making El Nino much more influential than positive IOD events.

\section{Introduction}

Agriculture plays a vital role in shaping the economy of developing countries like India. Agriculture along with its allied sector is the largest source of livelihoods in India particularly the rural populations. It provides them the main source of food, income and employment. India is the largest producer $(25 \%$ of global production), the consumer ( $27 \%$ of world consumption) and the importer $(14 \%)$ of pulses in the world (Mohanty et al. 2015). India is the second-largest producer of sugarcane after Brazil in the world and accounts for about $25 \%$ of the world's production (Upreti et al. 2017). Climatic conditions such as Temperature, Rainfall, humidity, sunshine, etc. have an impact on agriculture (Bhatla et al. 2019). India mostly receives rainfall during the summer monsoon season and some parts of the Northern India and Gangetic plains receive rainfall from the Western Disturbances. Indian Monsoon rainfall varies both in spatial as well as temporal scales. Spatial variations are mainly due to the geography of India. But temporal variations i.e., year to year variations in Indian monsoon rainfall mainly depend on El Nino Southern Oscillation (ENSO) and Indian Ocean Dipole through teleconnections which are called the important predictors of Indian Summer monsoon rainfall. This phenomenon can lead to an increase or decrease in rainfall, cloudiness, humidity, etc. and hence affecting the crops.

Indian Monsoon rainfall is extremely important for the agriculture of our country. Kharif crops are very much dependent on the summer monsoon rainfall and thus get affected due to the variation or fluctuations in the rainfall (Parthasarathy et al.1988; Gadgil et al. 1996; Webster et al. 1998). These crops 
get affected by the floods and the droughts that are associated with the mentioned climate modes in the different zones. It has been found that post-1980 variability in the Indian summer monsoon rainfall prediction has been increasing. Post-1988, the models even could not predict the Indian summer monsoon rainfall accurately (Wang et al. 2015). It has been found that the inverse relationship between El Nino (warm phase of ENSO) and the Indian summer monsoon rainfall has been weakening down post1980 (Krishnakumar et al. 1999). The prime reason is that there is a shift in the ENSO circulation to the southeast or southward of its original position in the recent decades as compared to that before the 1980s. This south eastward or southward shift in the walker circulation results in the descending motion to weaken over the Indian subcontinent and also the zone of strong subsidence has shifted southwards away from India. This results in an increment in the Indian summer monsoon rainfall even when the phase is El Nino (Krishnakumar et al. 1999). Even in the La Nina years after 1980, the rainfall over central India has also decreased as compared to the pre-1980s (Samanta et al. 2020). After the 1980s, La Nina's tends to weaken the Walker circulation that has resulted in anomalous subsidence over the Indian subcontinent. As a result, there is inhibition of deep convection that drives Indian summer monsoon rainfall (Samanta et al. 2020). Other leading modes of ENSO have appeared since 1990 i.e., the Central pacific ENSO (CP-ENSO). It has been found out that the CP-ENSO impacts the drought and flood events over India (Krishnakumar et al. 2006). Some more researches have emerged based on the observations of other teleconnections or events in recent decades. It has been observed that the Eurasian snowfall has decreased during the recent decades particularly the El Nino years. This decrease in snowfall has resulted in the rise in the temperature of the surface that in turn led to the further deepening of the heat low during the pre-monsoon seasons of the El Nino years (Krishna Kumar et al. 1999).

Indian summer monsoon rainfall over India has been changed due to the variation in the ENSO in recent years. The change in the rainfall pattern affects the growth as well as the production of the crops, specifically the Kharif crops which grow during the summer monsoon season. Crops mostly get affected in the drought or the flood years. The association of drought/flood with El Nino/La Nina has been described and studied overall in India and East Uttar Pradesh (Bhatla et al. 2016(a,b)). In recent times there are certain anomalous El Nino flood years as well as La Nina drought years in certain zones that have affected the production of the crop. The present study has shown the association of drought or flood years with El Nino and La Nina years as well as the effect of these flood or drought years on the crops over the agro-climatic zones of western India. It is thought that the IOD has a connection with ENSO events through an extension of the Walker circulation to the west of and associated Indonesian flow of warm tropical ocean water from the Pacific into the Indian Ocean. Hence, positive IOD events are often associated with El Nino and negative events with La Nina in the same year (Saji et al. 1999). The IOD which is induced can also provide feedback to the developing phase of ENSO (Behera and Yamagata 2003; Annamalai et al. 2005). When the IOD and ENSO are in phase, the impacts of El Nino and La Nina events are often most extreme over Australia, while when they are out of phase, the impacts of El Nino and La Nina events is very less.

In the recent decades, particularly the positive Indian Ocean dipole years, the Indian summer monsoon precipitation has been increased as compared to the negative dipole years. Although, it has also been 
found out that both the phases of Indian Ocean dipoles give a significant increase or decrease in monsoon rainfall over southern peninsular India (Bala et al. 2007). It shows very weak correlations over other zones. ENSO also has a relationship with the IOD. It has been found that most of the positive IOD years happen to be El Nino years also. Similarly, most of the negative IOD years also happens to be La Nina years. Ashok et al. 2001 have shown that the weakening of the ENSO-ISMR relationship is apparently due to the frequent occurrence of strong positive IOD events that have neutralized the impact of El Nino and Southern Oscillation; this is because the ISMR is positively correlated to the IOD mode index. IOD and ENSO variabilities during monsoon months (JJAS) indeed influence the monsoon variability (Ashok et al. 2007). The effect of these climatic modes such as ENSO on the crops has been studied over the IGP region (Bhatla et al. 2020) but the effects of the ENSO over the western agro-climatic zones of India has not been studied. The effect of IOD on crop productions over agro-climatic zones of India has never been studied. India is divided into fifteen agro-climatic zones based on the physiography, soil, climate, cropping patterns, and geological formation and development of irrigation and mineral resources for broad agricultural planning and developing future strategies. The present study is on the effects of the El Nino, La Nina and the IOD on the Kharif crops over the four arid/semi-arid agro-climatic zones of Western India from 1966 to 2011.

\section{Data And Methodology}

This study is based on the district-wise agricultural data from 1966 to 2011 for four crops namely rice, maize, pulses and sugarcane over four different western and central agro-climatic zones (ACZ) of India. These four agro-climatic zones are the Central plateau and hills region, Western plateau and hills region, Gujarat plains and hills region and Western dry region which are mentioned as CPHR, WPHR, GPHR \& WDR respectively. The districts of the states in each ACZs are shown in (Table 1). Several hot arid and semi-arid regions are considered. To study the impact of the El Nino, La Nina and IOD on the semi-arid and arid zones of western India. The yearly agriculture data have been obtained from International Crops Research Institute in Semi-Arid Tropics (ICRISAT-IN). The El Nino and La Nina conditions are found by the observations of SST anomalies at Nino 3.4 region of the Pacific Ocean. Nino 3.4 region is from $50 \mathrm{~N}-50 \mathrm{~S}$, 170oW-120oW (Fig. 1). Anomalies are the deviations from the mean SST of the data for each month of all the 46 years of our study. Since we are dealing with the Kharif season crops, we are rather more interested in the ONI (Ocean Nino Index) for the monsoon months (JJAS). The ONI data is taken from NOAA, Climate Prediction Centre (www.cpc.ncep.noaa.gov). The El Nino and La Nina years are found based on 5 or more consecutive seasons having 3-months mean of SST 3.4 anomalies are greater

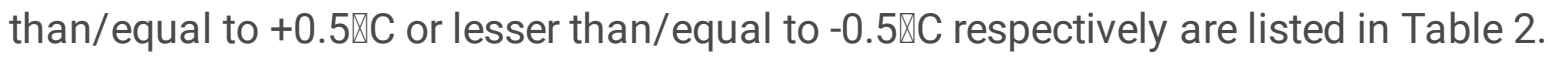


Table 1

Districts included in the different agro-climatic zones

\begin{tabular}{|c|c|c|c|}
\hline $\begin{array}{l}\text { Agro- } \\
\text { Climatic } \\
\text { Zones }\end{array}$ & Rainfall & States & District \\
\hline $\begin{array}{l}\text { Central } \\
\text { Plateau } \\
\text { and } \\
\text { Hills } \\
\text { region- } \\
\text { (CPHR) }\end{array}$ & $\begin{array}{l}629.9 \\
\mathrm{~mm}\end{array}$ & $\begin{array}{l}\text { Madhya } \\
\text { Pradesh, } \\
\text { Rajasthan } \\
\text { and Uttar } \\
\text { Pradesh }\end{array}$ & $\begin{array}{l}\text { Ajmer, Alwar, Banswara, Bharatpur, Bhilwara, Bundi, } \\
\text { Chittorgarh, Dungarpur, Kota, Pali, Sawai Madhopur, Sirohi, } \\
\text { Udaipur, Jabalpur, Chhindwara, Narsinghpur, Seoni, Mandla, } \\
\text { Sagar, Tikamgarh, Chhatarpur, Panna, Rewa,Sidhi, Satna, } \\
\text { Gwalior, Shivpuri,Guna, Datia, Morena, Bhind, Sehore, Raisen, } \\
\text { Vidisha, Betul, Hoshangabad, Jalaun, Hamirpur, Banda. }\end{array}$ \\
\hline $\begin{array}{l}\text { Western } \\
\text { Plateau } \\
\text { and } \\
\text { Hills } \\
\text { region- } \\
\text { (WPHR) }\end{array}$ & $\begin{array}{l}760.0 \\
\mathrm{~mm}\end{array}$ & $\begin{array}{l}\text { Madhya } \\
\text { Pradesh and } \\
\text { Maharashtra }\end{array}$ & $\begin{array}{l}\text { Indore, Ratlam, Ujjain, Mandsaur, Dewas, Dhar, Jhabua, } \\
\text { Khaegone, Khandwa, Rajgarh, Shajapur, Nasik, Dhulia, } \\
\text { Jalgaon, Ahmednagar, Pune, Satara, Sangli, Solapur, Kolhapur, } \\
\text { Aurangabad, Parbhani, Beed, Nanded, Osmanabad, Buldhana, } \\
\text { Akola, Amaravati, Yeotmal, Wardha, Nagpur. }\end{array}$ \\
\hline $\begin{array}{l}\text { Gujarat } \\
\text { Plains } \\
\text { and } \\
\text { Hills } \\
\text { region- } \\
\text { (GPHR) }\end{array}$ & $\begin{array}{l}210.6 \\
\mathrm{~mm}\end{array}$ & $\begin{array}{l}\text { Gujarat, } \\
\text { Dadra \& } \\
\text { Nagar } \\
\text { Haveli, } \\
\text { Daman \& } \\
\text { Diu }\end{array}$ & $\begin{array}{l}\text { Ahmedabad, Amreli, Banaskanth, Broach, Vadodara, } \\
\text { Bhavnagar, Valsad, Dang, Jamnagar, Junagarh, Kaira, Kheda, } \\
\text { Kutch, Mehsana, Panch-Mahal, Rajkot, Sabarkantha, Surat, } \\
\text { Surendranagar. }\end{array}$ \\
\hline $\begin{array}{l}\text { Western } \\
\text { Dry } \\
\text { region- } \\
\text { (WDR) }\end{array}$ & $\begin{array}{l}65.3 \\
\mathrm{~mm}\end{array}$ & Rajasthan & $\begin{array}{l}\text { Barmer, Bikaner, Churu, Jaisalmer, Jalore, Jhunjhunu, Jodhpur, } \\
\text { Nagaur, Sikar. }\end{array}$ \\
\hline
\end{tabular}


Table 2

List of El Nino, La Nina, neutral, positive IOD \& negative IOD years. Positive IOD years associated with El Nino are shown in red color and negative IOD years associated with La Nina are shown in blue color.

\begin{tabular}{|lllll|}
\hline La Nina & El Nino & Neutral & IOD Positive & IOD negative \\
\hline 1970 & 1969 & 1966 & 1972 & 1974 \\
\hline 1971 & 1972 & 1967 & 1982 & 1981 \\
\hline 1973 & 1977 & 1968 & 1983 & 1989 \\
\hline 1974 & 1982 & 1976 & 1994 & 1992 \\
\hline 1975 & 1987 & 1978 & 1997 & 1996 \\
\hline 1985 & 1991 & 1979 & 2006 & 1998 \\
\hline 1988 & 1994 & 1980 & & 2010 \\
\hline 1995 & 1997 & 1981 & & \\
\hline 1998 & 2002 & 1983 & & \\
\hline 1999 & 2004 & 1984 & & \\
\hline 2000 & 2006 & 1986 & & \\
\hline 2007 & 2009 & 1989 & & \\
\hline 2008 & & 1990 & & \\
\hline 2010 & & 1992 & \\
\hline 2011 & & 1993 & \\
\hline & & 1996 & \\
\hline & 2001 & & \\
\hline & & 2003 & & \\
\hline & & 2005 & & \\
\hline
\end{tabular}

The rainfall data considered for the study over the different regions are taken from the Indian Institute of Tropical Meteorology, Pune (www.tropmet.res.in). The drought and the flood years are calculated from the rainfall data, shown in Table3 for all four zones. 
Table 3

Drought and the flood years at different zones (Red colour indicating El Nino years and blue colour indicating La Nina years)

\begin{tabular}{|c|c|c|}
\hline Zones & Drought Years & Flood Years \\
\hline CPHR & $\begin{array}{l}\text { 1966, 1968, 1972, 1974, 1979, 1985, 1986, } \\
\text { 1987, 1989, 1991, 2000, 2002, 2004, 2007, } \\
2009\end{array}$ & $\begin{array}{l}\text { 1967, 1969, 1970, 1971, 1973, 1975, } \\
\text { 1977, 1978, 1983, 1990, 1994, 1996, } \\
\text { 1999, 2003, } 2011\end{array}$ \\
\hline WPHR & $\begin{array}{l}\text { 1968, 1971, 1972, 1974, 1982, 1984, 1985, } \\
1987,1995,1997,2001,2002,2004,2009\end{array}$ & $\begin{array}{l}\text { 1969, 1970, 1973, 1975, 1981, 1983, } \\
\text { 1988, 1990, 1994, 1998, 2005, 2006, } \\
2007,2010\end{array}$ \\
\hline GPHR & $\begin{array}{l}\text { 1968, 1969, 1972, 1974, 1979, 1982, 1985, } \\
\text { 1986, 1987, 1991, 1995, 1999, 2000, 2002, } \\
2009\end{array}$ & $\begin{array}{l}\text { 1970, 1973, 1975, 1976, 1977, 1983, } \\
\text { 1984, 1988, 1994, 1997, 2003, 2005, } \\
\text { 2006, 2007, } 2010\end{array}$ \\
\hline WDR & $\begin{array}{l}\text { 1968, 1969, 1971, 1972, 1974, 1980, 1982, } \\
\text { 1984, 1985, 1986, 1987, 1991, 1999, 2002, } \\
\text { 2004, 2005, 2009 }\end{array}$ & $\begin{array}{l}\text { 1970, 1973, 1975, 1976, 1977, 1978, } \\
\text { 1983, 1990, 1992, 1994, 1995, 1996, } \\
\text { 2006, 2010, 2011 }\end{array}$ \\
\hline
\end{tabular}

The positive and negative Indian Ocean Dipole intensity of the IOD is represented by anomalous SST gradient between the western equatorial Indian Ocean $\left(50^{\circ} \mathrm{E}-70^{\circ} \mathrm{E}\right.$ and $\left.10^{\circ} \mathrm{S}-10^{\circ} \mathrm{N}\right)$ and the southeastern equatorial Indian Ocean $\left(90^{\circ} \mathrm{E}-110^{\circ} \mathrm{E}\right.$ and $\left.10^{\circ} \mathrm{S}-0^{\circ} \mathrm{N}\right)$. The regions are shown in Fig. 1. This gradient is named as Dipole Mode Index (DMI). The DMI values are taken from NOAA, Physical Science Laboratory (www.psl.noaa.gov). Positive and negative IOD events during monsoons were calculated and verified with IOD years mentioned on the website of BOM Bureau of Meteorology, Australia

(http://www.bom.gov.au/climate/iod/). The DMI is averaged for the positive and negative IOD years only for the monsoon months (JJAS). Its association has been studied by correlation coefficient analysis with the crops and ISMR of the different zone. The crop production data for the entire period 1966-2011 was de-trended each time by taking the difference, $\mathrm{Zi}=\mathrm{Zi}-\mathrm{Zi}-1$ between the value $\mathrm{Z}$ in each year $\mathrm{i}$, and the value in the previous year $\mathrm{i}-1$ (Box and Jenkins 1976). Trend analysis is also done for the crop production for the entire time series from 1966-2011 using the Mann-Kendall trend test. The significance tests of the correlation coefficients are also done using the student's t-test.

\section{Result And Discussion}

\subsection{Distribution of crop production and variation over different zones:}

The variation in production of the crops over the Central plateau and hills regions (CPHR) in the period of 1966-2011 are shown in Fig. 2(a). From this figure, it is seen that pulses are the majorly grown crops. Other than that, maize and rice crops are also grown well in this region but the quantity of its productions are not as high as compared to the pulses. Sugarcane production is minimum in this region. This zone includes the regions of eastern Rajasthan and Madhya Pradesh which usually receive sufficient rainfall during the monsoon season and remain mostly dry otherwise and hence are perfectly suitable for pulses 
production. It is known that the pulses are mostly found over the semi-arid zones of India. This agroclimatic zone is also a hot semi-arid zone. Cloudy weather or rains at flowering and fruiting stages of the pulses can result in poor pod setting and seed filling and hence lead to increased damage by pod borers (Sardana et.al 2010). Mann Kendall trend test shows that there is a monotonic increasing trend with more than $99 \%$ confidence ( $p$-values $<<0.01$ ) for all the crops in this zone (Table4).

Table 4

P-values for different crops at four agro-climatic zones using Mann-Kendall Trend test (With trend shown in up arrow represents the positive trend whereas the down arrow showing negative trends. Red colour represents the p-values greater than 0.05 i.e. insignificant)

\section{Zones Rice ( $p$-values) Maize (p-values) Pulses ( $p$-values) Sugarcane(p-values)}

\section{[P-values $=0.02: 98 \%$ confidence level; $p$-values $=0.01: 99 \%$ confidence level; $p$-values $=0.05: 95 \%$} confidence level]

Figure 2(b) depicts the variation in crop production over the Western plateau and hills region (WPHR) from 1966-2011. In this zone, climatic conditions are moderately humid as well as very hot. The regions include southern parts of Madhya Pradesh and central and eastern parts of Maharashtra which receives a good amount of rainfall during the monsoons. In other seasons, it is usually dry. This region receives about $50-100 \mathrm{~cm}$ of rainfall (Rainfall statistics of India 2016). From the figure, it is clear that sugarcane is

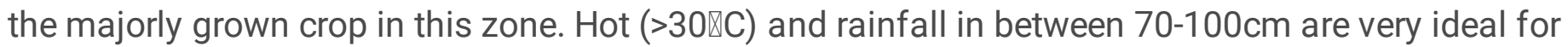
sugarcane production (Shukla et al 2017). Pulses are also grown well in this region. Rice and maize productions are not very high. Mann Kendall trend test shows that all the crops except rice have a monotonic increasing trend over this region with more than $99 \%$ confidence whereas rice crop has a monotonic increasing trend with 98\% confidence level (Table4). Figure 2(c) shows the variation of crop productions over the Gujarat plains and hills region (GPHR). The name itself suggests that the region in this zone is in Gujarat. Most of the parts of Gujarat receive an annual rainfall of between $50-100 \mathrm{~cm}$. Sugarcane and rice are the majorly grown crops in this zone. After 1980, the production of sugarcane has increased as compared to rice. Maize and pulses are also grown well in this zone. All the crops have a monotonic increasing trend at more than $99 \%$ confidence level (Table4). Figure 2(d) depicts the variation in crop productions over the Western Dry region (WDR). This zone includes the region of western Rajasthan. The climatic conditions are very dry throughout the year. Monsoon rainfall is also quite low over this zone. Pulses are majorly grown in this zone as it requires slightly dry conditions with high temperatures. The water remains available because of the Indira Gandhi canal which is there over the Western Rajasthan and the rainfall that the zone receives during the monsoon. There are negligible productions of other crops. Using the Mann Kendall trend test, it is seen that pulses have a monotonic increasing trend at more than $99 \%$ significance level (Table4).

The percentage contributions of the crop production at the four different agro-climatic zones throughout 1966-2011 are shown in Fig. 3. The percentage contribution of rice production at CPHR, WPHR \& GPHR are $17 \%, 9 \%$ and $31 \%$ respectively. At WDR, rice production is negligible. Maize production percentage contributions over CPHR, WPHR \& GPHR are $25 \%, 13 \%$ \& $17 \%$ respectively. Over WDR, the maize 
productions are also negligible. Pulses are the majorly grown crops over CPHR and WDR with percentage contributions of $53 \%$ and approximately $100 \%$ respectively. At WPHR, GPHR, the percentage contribution of pulses is $28 \%$ and $16 \%$ respectively. Sugarcane is the majorly grown crop over WPHR and GPHR with percentage contributions of $50 \%$ and $36 \%$ respectively. Sugarcane productions are very negligible over WDR. At CPHR, the percentage contributions are $5 \%$.

3.2 Association between crop productions with ONI/DMI and rainfall during El Nino, La Nina and positive/negative IOD years:

Crops are highly dependent on Indian summer monsoon rainfall (June to September). The correlations of the crops with ONI (Ocean Nino index) and with the rainfall during El Nino, La Nina, positive IOD and negative IOD years are shown in Table5, 6, 7 and 8 respectively. In general, ' $r$ ' is representing correlation coefficients. The student's t-test has been performed to check the confidence level of the correlations. " + " sign represents confidence level more than or equal to $90 \%, "++$ " sign refers to the confidence level more than $95 \%$.

Table 5

Correlation coefficients for four crops at 4 different zones with ONI \& rainfall during El Nino years [more than or equal to $90 \%$ confidence level: + , more than or equal to $95 \%$ confidence level: ++$]$

\begin{tabular}{|lllllllll|}
\hline Crops & CPHR & & WPHR & \multicolumn{3}{c|}{ GPHR } & \multicolumn{3}{l|}{ WDR } \\
\hline & ONI & Rainfall & ONI & Rainfall & ONI & Rainfall & ONI & Rainfall \\
\hline Rice & -0.44 & $0.51+$ & -0.30 & 0.34 & -0.32 & $0.67++$ & -0.23 & 0.37 \\
\hline Maize & -0.10 & -0.28 & -0.27 & 0.00 & 0.25 & 0.08 & 0.46 & 0.32 \\
\hline Pulses & -0.04 & 0.00 & -0.31 & 0.22 & -0.13 & $0.59++$ & -0.11 & $0.73++$ \\
\hline Sugarcane & -0.14 & 0.26 & -0.34 & 0.33 & -0.19 & $0.55+$ & 0.14 & 0.19 \\
\hline $\begin{array}{l}\text { Table6: Correlation coefficients for four crops at 4 different zones with ONI \& rainfall during La Nina } \\
\text { years [more than or equal to 90\% confidence level: }+ \text {, more than or equal to 95\% confidence level: ++] }\end{array}$ \\
\hline
\end{tabular}

Table5 shows that during the El Nino years, the rice crop has the strongest correlation with rainfall with more than $95 \%$ confidence level having $r=0.67$ over GPHR. Pulse crop on the other hand has the strongest correlation with rainfall over WDR with $95 \%$ confidence level having $r=0.73$. From Table 6 , it can be seen that there are no significant correlations with $\mathrm{ONI}$ in any zones during the La Nina years. But rice and maize have positive correlations with rainfall at GPHR with $r=0.44$ having more than $90 \%$ confidence and $\mathrm{r}=0.51$ having more than $95 \%$ confidence level. In Table7, during the positive IOD years, sugarcane has the strongest negative correlations with DMI (Dipole mode index) over CPHR with more than $95 \%$ confidence level having $r=-0.80$ and have a strong correlation with rainfall over GPHR with more than $95 \%$ confidence level having $r=0.90$. Pulses have the strongest correlation with rainfall at CPHR with more than $90 \%$ confidence level having $r=0.74$. Maize has the strongest correlation with rainfall over WPHR having $r=0.73$ with more than $90 \%$ confidence level. Rice crop is having the strongest correlation 
with rainfall over GPHR with $r=0.92$ with more than $95 \%$ confidence level. From Table 8, during the negative IOD years, rice crops have the strongest correlations with rainfall over GPHR with $r=0.88$ having more than $95 \%$ confidence level. The maize crop is also having the strongest correlation with the rainfall over the same zone with more than $95 \%$ confidence level having $r=0.82$. Pulses have the strongest correlation with DMI with more than $95 \%$ confidence level over WDR having $r=0.63$ \& rainfall having more than $95 \%$ confidence level with $r=0.89$ over GPHR. A negative correlation with DMI (negative for negative IOD years) means that when the DMI is strongly negative, crop production increases. Sugarcane has a strong correlation with DMI with more than $90 \%$ confidence level having $r=0.68$ over WPHR. At CPHR, WPHR and GPHR, all the crops are showing positive correlations with rainfall during positive as well as negative IOD years. During the EI Nino years, over CPHR and WPHR, all the crops are negatively correlated with ONI.

3.3 Impact of deviation of crop production from its previous year (detrending of production) during El Nino, La Nina, positive and negative IOD years:

Figure 4(a-d) shows the variation in the crop productions as compared to the previous year (detrending) for all the zones from 1-4 for rice, maize, pulses and sugarcane respectively. In the figure, the " $E$ " represents El Nino year, "L" represents La Nina year, "+" represents positive IOD year only and "(-)" represents negative IOD years only. Combined El-Nino positive years are denoted by " $(E+)$ " and combined La Nina negative IOD years are denoted as "(L-)".

There was total of 12 El Nino years and 15 la Nina years and 19 neutral years. But, here 18 neutral years are to be considered as the detrending analysis does not include 1966 which is a neutral year. From Fig. 4(a) i.e., for rice productions, it is observed that over CPHR i.e., Central Plateau and Hills region, 4 out of $12 \mathrm{El} \mathrm{Nino} \mathrm{years} \mathrm{are} \mathrm{giving} \mathrm{positive} \mathrm{production} \mathrm{of} \mathrm{rice} \mathrm{i.e.,} \mathrm{increment} \mathrm{in} \mathrm{production} \mathrm{as} \mathrm{compared} \mathrm{to} \mathrm{the}$ previous year. This is about $33 \%$ of the total number of El Nino years. The remaining $67 \%$ of the total El Nino years are severely impacting rice production. There are 6 El Nino drought years out of which only 1 year is giving positive production of rice. There are 3 combined El Nino flood years, in all these, there is an increment in rice production from the previous year. Rainfall and crop productions are positively correlated during the El Nino years with more than $90 \%$ significance level with $(r=0.51)$. There is a total of 15 la Nina years out of which 4 La Nina years are negatively associated with rice production. This is only $27 \%$ years of the total La Nina years. This is giving a clear indication that rice production is mostly high in La Nina years. There is the total of 6 La Nina flood years. In all these years, the rice production has increased w.r.t its previous year. There are only 4 combined La Nina drought years out of which there are 3 years when the rice production is negatively associated. 8 out of 18 neutral years are associated negatively with rice production. Out of 6 positive IOD years, 2 years are positively associated with rice production. The other 4 years are combined El Nino and positive IOD years. In these years, the impact of El Nino is more than the impact of positive IOD on rainfall and hence affects rice production as it is strongly dependent on rainfall. It has been found out that in the combined El Nino and positive IOD years, the correlation between positive IOD and rainfall is $r=0.10$ (not significant), and the correlation between $\mathrm{EI}$ 
Nino and rainfall is $r=-0.59$ (albeit insignificant) (Table10). 3 out 7 negative IOD years are associated with negative rice production. Out of these 3 years, 2 years are complete negative IOD years.

Moving on towards the Western plateau and Hills region (WPHR), out of 12 El Nino years, only 4 years are associated with the positive production of rice. This suggests that the El Nino years are giving a negative impact on the rice production in the mentioned zone. 1 year out of 7 combined El Nino and drought years are associated with the increment in rice production. 2 out of 3 combined El Nino and flood years are associated with positive production of rice. 7 years out of $15 \mathrm{La}$ Nina years are associated negatively with rice production. The remaining 8 years are related positively to rice production. All the 7 combined La Nina and flood years are positively associated with the production of rice. The 4 years that are combined La Nina but drought years, the rice production is negatively associated. 8 out of 18 neutral years are negatively associated with rice production. 4 out of 6 IOD positive years have a negative impact on rice production. All these 4 years are El Nino years. Correlations between $\mathrm{ONI}$ and rainfall during the El Nino combined with positive IOD years is $r=-0.80$ (significant up to $90 \%$ confidence level) on the other hand the correlation between DMI and rainfall is $r=-0.51$ (insignificant) (Table10). This indicates El Nino has more impact on the rainfall than positive IOD in the combined years. 2 out of 7 IOD negative years are associated with a decrement in rice production as compared to previous years. One is a pure negative IOD year. There are 3 La Nina years associated with negative IOD years in which 2 years have positive production and one year have decrement of rice production.

Over GPHR i.e., Gujarat hills and plains region, rice crop has a maximum increasing trend of 25.27kT/year during 1966-2011 (Table9 \& Fig. 5). In this zone, out of 12 El Nino years, there are 5 years in which the rice production has increased from the just previous year. 1 out of $7 \mathrm{EI} \mathrm{Nino} \mathrm{and} \mathrm{drought} \mathrm{combined} \mathrm{years} \mathrm{are}$ positively associated with rice production. 3 out of 4 combined El Nino flood years are showing an increment in rice production. This is also justified as the rainfall is positively correlated with the rice production ( $r=0.67)$ up to more than $95 \%$ confidence level. There are $7 \mathrm{La}$ Nina years out of 15 years, in which the rice production has decreased from its previous year. The combined La Nina and flood years are positively associated with rice production. All the 5 combined La Nina drought years are negatively associated with rice production. There are in total 8 neutral years out of total 18 years, when the rice production has decreased from the previous year. Looking at the positive IOD years, 3 positive IOD years are associated negatively with rice production. These are all El Nino years as well. The effect of El Ninorainfall correlation of $\mathrm{ONI} \&$ rainfall is $r=-0.44$ (although not significant) is dominant as compared to the IOD-rainfall whose correlation between DMI and rainfall is $r=-0.13$ (not significant) (Table10). In the negative IOD years, 3 out of 7 negative IOD years are associated with a decrement in the production of rice. Out of all these 3 years, 2 years are pure negative IOD years. It is known that negative IOD years usually results into negative rainfall anomaly in most of the places of our country (Ashok et.al 2004). There are 14 drought years out of 15 years when the rice production shows a decrement from the just previous year. There are 2 flood years out of 15 years are associated with the decrement in the rice production. 
Figure 4(b) represents the effect of El Nino, La Nina, positive IOD and negative IOD years on the maize production. Over CPHR i.e., Central Plateau and Hills region, out of total 12 El Nino years, 2 are positively associated with the maize production that is nearly $17 \%$ of the total El Nino years. El Nino is giving a strong negative impact on maize production. All the $6 \mathrm{El} \mathrm{Nino} \mathrm{and} \mathrm{drought} \mathrm{combined} \mathrm{years} \mathrm{are}$ associated with negative production of the maize. 2 combined El Nino flood years are negatively associated with maize production out of 3 years. 6 out of 15 la Nina years are associated with a decrement in the production of maize. 3 out of 6 La Nina flood years are associated with the negative production of maize. 3 years out of 4 combined La Nina drought years are positively associated with maize production. 8 out of 18 neutral years are affecting maize production. 2 out of 6 positive IOD years are positively associated with maize production. All four positive IOD years are El Nino years. As already discussed, the El Nino seems to affect the rainfall more than the positive IOD and hence production decrement is seen (Table10). Only 1 out of 7 negative IOD years are negatively associated with maize production.

Maize crop production shows the maximum increasing trend of 48.73kT/year over the period from 19662011 (Table9, Fig. 5) over WPHR i.e., Western plateau and Hills region. There are 4 El Nino years in which the maize production is positively associated i.e., w.r.t the previous year the production has increased. The remaining El Nino years have a negative association. 3 out of 7 combined El Nino and drought years are positively associated with maize production. 1 out of 3 combined El Nino flood years is positively associated with maize production. There are 6 La Nina years out of 15 where the maize production has decreased as compared to its previous year. The remaining years are positively associated i.e. the maize production has increased as compared to the previous year. 2 out of 4 combined La Nina and drought years are negatively associated with maize and 1 out of 7 combined La Nina and flood years is negatively associated with maize production. 7 out of 18 neutral years are negatively associated with maize production. There are 3 years out of 6 positive IOD years when the maize productions are severely affected. All these 3 years are combined El Nino positive IOD years. Over WPHR also, the El Nino-rainfall correlations are stronger than the positive IOD-rainfall correlations (Table10). Only one year out of seven negative IOD years is there in which maize production has been affected negatively.

Over Gujarat hills and plains region (GPHR), only 2 years out of 12 El Nino years are associated with the positive production (Increase from the previous year). 1 out of 7 combined El Nino drought years is positively associated with maize production. 3 out of 4 combined El Nino flood years are negatively associated with maize production. 6 years out of total 15 La Nina years are negatively affecting crop production. 3 out of 5 combined La Nina drought years are negatively associated with maize production and 1 out of 6 combined La Nina flood years is negatively associated with maize. There are 7 neutral years out of 18 that are negatively associated with maize production. There are 4 positive IOD years out of 6 years which are associated with a decrement in maize production. These all are combined El Ninopositive IOD years. The reason may be El Nino is affecting the production as compared to positive IOD (Table10). There is only one negative IOD year out of seven years which is negatively affecting the maize production i.e., 1981. Over WDR i.e., the Western Dry region, maize production is very negligible 
Figure 4(c) shows the impacts of the climate modes on pulse productions. It is observed that in CPHR i.e., Central Plateau and Hills region, pulses production shows a maximum increasing trend of $58.08 \mathrm{kT} / \mathrm{year}$ from 1966-2011 (Table9, Fig. 5). Out of 12 El Nino years, 3 El Nino years are associated with positive production of pulses. 2 years out of $3 \mathrm{El}$ Nino years as mentioned are flood years. This indicates that $75 \%$ of the El Nino years are impacting negatively in pulse production. There are $6 \mathrm{El} \mathrm{Nino}$ and drought combined years in which the pulse production has been negatively impacted. 1 out of $3 \mathrm{El}$ Nino flood years is negatively associated with pulse production. But 7 out of $15 \mathrm{La}$ Nina years are negatively associated with pulse production. Excessive rainfall during la Nina years may affect production. Cloudy weather or rains at flowering and fruiting stages of the pulses can result in poor pod setting and seed filling leading to crop damage (Sardana et.al 2010). 2 La Nina and flood combined years out of 6 are negatively associated with pulse production. Out of 4 combined La Nina drought years, two years are associated with the decrement of pulse production. 6 out of 18 neutral years are negatively associated with pulse production. 3 out of 6 positive IOD years are positively associated with pulse production. The other 3 are combined El Nino and positive IOD years. In these years, over this region, El Nino has a greater impact on rainfall than IOD [Table10]. Only 1 out of 7 negative IOD years are negatively associated with pulses production. Pulse is the majorly grown crop out of all other crops in this zone. 3 out of 14 drought years are associated positively with the pulses i.e., the major grown crops. 3 out of 15 flood years are negatively associated with negative pulse production. Drought years in this zone are decreasing the production of the crops.

Over the Western plateau and Hills region (WPHR), $50 \%$ of the El Nino years are positively associated with pulses production. 6 years out of 15 La Nina years are negatively impacting the pulses production. The decrement of pulses in these years is low as compared to the previous years. 4 out of 7 combined El Nino and drought years are positively associated with pulse production. Pulses production requires somewhat dry conditions. 2 out of 3 combined El Nino and flood years are positively associated with the pulse production. 1 out of 7 combined La Nina flood years is negatively associated with pulse production whereas 2 out of 4 combined La Nina drought years are negatively associated with pulse production. 7 out of 18 neutral years are negatively associated with pulse production. 3 years out of 6 positive IOD years which happens to be El Nino years as well and are negatively associated with the production of the crop as compared to positive IOD (Table10). Only 1 year out of 7 negative IOD years are affecting the pulse crop production. Gujarat hills and plains region representing the semi-arid areas and some arid regions of Gujarat i.e., over GPHR, only $1 \mathrm{El}$ Nino year is associated with the increase in the production of pulses. Only 1 out of $7 \mathrm{El}$ Nino drought years is positively associated with pulses production. All 4 combined El Nino flood years are negatively associated with pulse production. $7 \mathrm{La}$ Nina years are associated with the decrement of pulses production. All 5 combined La Nina drought years are negatively associated with pulse production. Moreover, all the 6 La Nina flood years are positively associated with pulse production. There was total 4 neutral years out of 18 neutral years that have negatively association with pulses production. Four (4/6) out of six positive IOD years are associated with decrement in pulse production. All four years are combined El Nino- positive IOD years. The reason may be El Nino is 
affecting the production as compared to positive IOD (Table10). There are 2 negative IOD years which are associated with the decrement in the pulse production out of 7 years.

Pulses are the majorly grown crops in WDR i.e., the Western dry region. Here, the other crops production is extremely small. So, we will consider only pulse production. 6 out of 12 El Nino years is associated with the increment in pulse production as compared to the previous year. There are $8 \mathrm{El} \mathrm{Nino} \mathrm{and} \mathrm{drought}$ combined years out of which two are positively associated with the pulses production. On the other hand, 6 out of 15 La Nina years are associated with decrement in pulse production as compared to the previous year. Only 2 out of 6 La Nina and flood combined years are negatively associated with the pulses production. 10 out of 18 neutral years are resulting into decrease in pulse production over this zone. All the $3 \mathrm{El}$ Nino flood years are positively associated with pulses production. Three $(1971,1974$ \& 1999) La Nina drought years out of 4 are decreasing pulse production. There are 4 drought years out of 17 are associated with an increase in pulses production. 4 out of 15 flood years are associated with a decrement in pulse production. In positive IOD years, there is only one year which is also an El Nino year that is associated with the decrement in pulse production. On the other hand, 4 out of 7 negative IOD years are associated with a decrement in pulse production. Out of them, two are pure negative IOD years and have negative rainfall anomalies associated with it in the zone [Ashok et.al (2004)]. Two others are combined La Nina negative IOD years.

Figure 4(d) represents the impacts of the climate modes mentioned above on sugarcane production. Over CPHR i.e., Central Plateau and Hills region, out of $12 \mathrm{El} \mathrm{Nino} \mathrm{years,} 9$ years have a positive association with the sugarcane production where six years are even drought years in the region. Although the increment in these El Nino years is small i.e., 4 years have below 10 Ktonnes increment w.r.t previous year. In these, in 4 drought El Nino years, increment of sugarcane production is seen but is very small increase as compared to the previous year. There are $3 \mathrm{El} \mathrm{Nino} \mathrm{flood} \mathrm{years} \mathrm{that} \mathrm{are} \mathrm{positively} \mathrm{associated} \mathrm{with}$ sugarcane production as the correlation of Sugarcane production with rainfall is 0.26 during El Nino years. El Nino years generally give less than normal monsoon rainfall and Sugarcane production requires sufficient rainfall. The contrasting results may be due to better irrigation techniques and the varieties of Sugarcane grown in these areas. For example, a variety of Sugarcane which is CoPant 90223 identified in the year 2000 is tolerant to several diseases and tolerant to drought (ICAR-Sugarcane Technologies2015). 6 out of 15 La Nina years are negatively associated with sugarcane production. Only 2 out of $6 \mathrm{La}$ Nina flood years are negatively associated with sugarcane production. Out of 4 combined La Nina drought years in this zone, 2 years are positively associated with sugarcane production. 11 out of 18 neutral years are negatively associated with sugarcane production. It is observed therefore that neutral years are not very suitable to grow Sugarcane. 4 out of 6 positive IOD years are positively associated with sugarcane production. One of these is a pure positive IOD year which is associated with positive rainfall anomaly over the zone (Ashok et al. 2004). 3 out of 7 negative IOD years are negatively associated with sugarcane production. All are pure negative IOD years which usually have negative rainfall anomalies over certain parts of the zone (Ashok et al. 2004). Sugarcane production shows a strongest increasing trend over the years 1966-2011 i.e. 121.84kT/year (Table9, Fig. 5) at WPHR i.e. Western plateau and Hills region. Out of $12 \mathrm{El}$ Nino years, 8 are there where there is a good production of sugarcane. Sugarcane 
production requires 2-3 seasons of rainfall and then drought or low rainfall period. Irrigation is required in almost all phases of its growth (Srivastava et al. 2012). Irrigations along with short rainfall in El Nino years may be giving good production and providing a minor impact on the crop. Only 4 out of 15 La Nina years are associated with a decrement of sugarcane production as compared to previous years. 4 out of 7 combined El Nino drought years are positively associated with sugarcane whereas 3 combined El Nino flood years are positively associated with sugarcane production. All 7 combined La Nina flood years are positively associated with sugarcane production. 2 out of 4 La Nina drought years are negatively associated with sugarcane. 10 out of 18 neutral years are negatively associated with sugarcane production. Only 2 years out of 6 positive IOD years are there in which the sugarcane production has shown decrement. Only 1 year out of seven negative IOD years are negatively affecting sugarcane production.

At GPHR i.e., Gujarat hills and plains region, out of 12 El Nino years, 7 years are associated with the increment in sugarcane production. The reason for the minor impact of Sugarcane in El Nino years may be due to better irrigation technique that provides sufficient water. Drought conditions are also required after 2-3 good spells of rainfall. El Nino years provides the same condition. Even if the rainfall is little, irrigation if done properly at each stage of development can lead to good production (Srivastava et al. 2012). On the other hand, 5 out of 7 Combined El Nino and drought years are positively associated with sugarcane production. 2 out of 4 combined El Nino flood years are positively associated with sugarcane production. There are $7 \mathrm{La}$ Nina years out of 15 years where the sugarcane production has decreased from just the previous year. 3 out of 6 combined La Nina and flood years are associated with negative sugarcane production. 3 out of 5 combined La Nina drought years are negatively associated with sugarcane production. There are 7 neutral years out of 18 years when sugarcane production has decreased. Here, neutral years are suitable for good sugarcane productions. 3 out of 6 positive IOD years are associated with decrease in sugarcane production. All are combined EI Nino IOD years. Only two negative IOD years out of seven years are associated with decrement in sugarcane production. 7 out of 15 drought years are negatively associated with sugarcane production. 7 flood years out of 15 years are negatively associated with sugarcane production. Sugarcane is hardly grown over the WDR i.e., the Western Dry region.

Table6: Correlation coefficients for four crops at 4 different zones with ONI \& rainfall during La Nina years [more than or equal to $90 \%$ confidence level: + , more than or equal to $95 \%$ confidence level: ++ ]

\begin{tabular}{|lllllllll|}
\hline Crops & CPHR & \multicolumn{3}{c}{ WPHR } & GPHR & WDR \\
\hline & ONI & rainfall & ONI & rainfall & ONI & rainfall & ONI & rainfall \\
\hline Rice & -0.24 & 0.28 & -0.17 & 0.21 & -0.02 & $0.44+$ & 0.12 & 0.18 \\
\hline Maize & 0.05 & -0.30 & 0.03 & 0.10 & -0.29 & $0.51++$ & 0.03 & -0.09 \\
\hline Pulses & 0.18 & -0.15 & -0.14 & 0.12 & -0.01 & 0.39 & -0.13 & $0.46+$ \\
\hline Sugarcane & 0.24 & -0.27 & 0.12 & -0.01 & 0.21 & -0.13 & 0.10 & -0.18 \\
\hline
\end{tabular}


Table7: Correlation coefficients for four crops at 4 different zones with DMI \& rainfall during positive IOD years [more than or equal to $90 \%$ confidence level: + , more than or equal to $95 \%$ confidence level: ++ ]

\begin{tabular}{|lllllllll|}
\hline Crops & CPHR & \multicolumn{3}{c}{ WPHR } & GPHR & WDR \\
& DMI & rainfall & DMI & Rainfall & DMI & rainfall & DMI & rainfall \\
\hline Rice & -0.06 & 0.84 & -0.52 & $0.78+$ & -0.16 & $0.92++$ & -0.25 & -0.54 \\
\hline Maize & -0.58 & 0.06 & -0.58 & $0.73+$ & 0.26 & 0.21 & 0.63 & -0.48 \\
\hline Pulses & -0.06 & $0.74+$ & -0.57 & $0.73+$ & -0.50 & 0.69 & -0.10 & 0.62 \\
Sugarcane & $-0.80++$ & 0.16 & -0.52 & 0.65 & -0.16 & $0.90++$ & -0.39 & 0.10 \\
\hline
\end{tabular}

Table8: Correlation coefficients for four crops at 4 different zones with DMI \& rainfall during negative IOD years [more than or equal to $90 \%$ confidence level: + , more than or equal to $95 \%$ confidence level: ++ ]

\begin{tabular}{|lllllllll|}
\hline Crops & CPHR & \multicolumn{3}{c}{ WPHR } & \multicolumn{3}{c|}{ GPHR } & WDR \\
\hline & DMI & rainfall & DMI & Rainfall & DMI & rainfall & DMI & rainfall \\
\hline Rice & 0.43 & 0.50 & -0.32 & $0.76++$ & 0.38 & $0.88++$ & $0.72+$ & 0.44 \\
\hline Maize & 0.53 & 0.13 & 0.62 & 0.55 & 0.43 & $0.82++$ & -0.76 & 0.06 \\
Pulses & 0.06 & $0.79++$ & 0.48 & 0.61 & -0.08 & $0.89++$ & $0.63++$ & 0.65 \\
Sugarcane & 0.00 & 0.62 & $0.68+$ & 0.65 & -0.03 & 0.54 & -0.54 & -0.33 \\
\hline
\end{tabular}

Table9: Rates of increment/decrement of crop production (in kT/year) over the years 19662011 (maximum increasing trend is shown in red)

\begin{tabular}{|lllll|}
\hline Crops & CPHR & WPHR & GPHR & WDR \\
\hline Rice & 13.60 & 5.94 & 25.27 & -0.001 \\
\hline Maize & 32.21 & 48.73 & 11.07 & -0.02 \\
\hline Pulses & 58.08 & 52.31 & 10.27 & 17.34 \\
\hline Sugarcane & 1.86 & 121.84 & 40.84 & -0.007 \\
\hline
\end{tabular}

Table10: Correlation of rainfall with ONI and DMI for combined El Nino-positive IOD years from 19662011. (* significant upto $90 \%$ confidence level) 


\begin{tabular}{|lll|}
\hline Zones & Rainfall \& ONI & Rainfall \& DMI \\
\hline CPHR & -0.59 & 0.10 \\
\hline WPHR & $-0.80 *$ & -0.52 \\
\hline GPHR & -0.44 & -0.13 \\
\hline WDR & -0.46 & -0.26 \\
\hline
\end{tabular}

\section{Conclusions}

The effect of El Nino, La Nina as well as IOD on the four agro-climatic zones of western India are studied by considering four Kharif season crops namely rice, maize, pulses and sugarcane from 1966 to 2011. There are many factors on which the crop production over a zone depends upon such as Maximum and minimum temperature, relative humidity, rainfall, Sunshine hours, etc. Here, mostly based on monsoon rainfall, the study has been done. Based on the observations of the productions of these crops due to the effect of the teleconnections on monsoon rainfall, the following conclusions are made.

Overall zones, El Nino seems to affect rice production especially the drought years. El Nino years particularly drought years give less than normal rainfall. Hot \& humid climates are very suitable for rice production. The scarcity of soil moisture reduces the production of rice. La Nina years are very good for the production of rice over all the zones of our study. Pulses are the dominant crop in two zones namely CPHR and WDR. Pulses are mostly affected in the El Nino years most specifically the drought years associated with El Nino in both zones. Even the La Nina years also negatively affecting the pulse production but not as much as in the El Nino years. Neutral years are seen to be best suited for the production of pulses in any agro-climatic zones considered in our study. Sugarcane is the dominant crop in WPHR and GPHR. In almost all the zones, El Nino and La Nina years are associated with good sugarcane production. El Nino particularly has a minor impact on Sugarcane production. On the other hand in GPHR, sugarcane is grown well in the neutral years and La Nina years. Some four-five El Nino and La Nina years seem to affect the production of sugarcane in CPHR and WPHR. Neutral years have affected Sugarcane productions over these zones. For Sugarcane productions, La Nina years are suitable. Maize crop, although not a dominant crop in any zone but when the observations are analyzed, it is seen that El Nino years are severely affecting the maize production especially the drought years associated with El Nino. La Nina years, as well as neutral years, are suitable for maize production in any of the mentioned zones. Positive IOD years are affecting the rice production in the mentioned zones negatively as almost all positive IOD years are El Nino years also. It has been seen that the rice production gets worst affected in El Nino years. On the other hand, negative IOD years show a better result in terms of rice production over all zones of our study. Mostly all the crops considered in our study zones shows better result in terms of its production in the negative IOD years as compared to that in positive IOD years. But there is an exception, pulses in WDR shows slightly better productions in positive IOD years than negative IOD year. 


\section{Declarations}

Acknowledgments:

The author wants to thank the Indian Institute of Tropical Meteorology (IITM, Pune) for providing the rainfall data required in the study, NOAA, Climate Prediction Centre for ONI data and NOAA, Physical Science Laboratory for DMI data and also thank the Bureau of Meteorology (BOM) for positive and negative IOD year's data. The author also wants to thank International Crops Research Institute for SemiArid Tropics (ICRISAT-IN) for providing crop production data.

Author contribution: R.B. helps in conceptualization of the study. S.B. and S.V. have analysed the data and provide methodology. R.K.M. and R.S.S. has guided in agriculture section, review and editing of the manuscript. S.G., S.V. and R.B. completed the writing of original manuscript the paper.

Funding: This project was funded by the Department of Science and Technology (DST), Ministry of Earth Science (MoES), Govt. of India in the form of the Centre for Excellence in Climate Change.

Data availability: All data generated or analysed during this study are included in this published article.

Code availability: Not required

Ethics approval: For this type of study formal approval is not required.

Consent to participate: For this type of study formal consent is not required.

Conflict of interest: The authors declare no conflict of interest.

Consent for publication: For this type of study consent for publication is not required.

\section{References}

1. Annamalai HS, Xie SP, McCreary JP, Murtugudde R (2005) Impact of Indian Ocean sea surface temperature on developing El Niño. J Clim 18(2):302-319

2. Ashok K, Saji NH (2007) On the impacts of ENSO and Indian Ocean dipole events on sub-regional Indian summer monsoon rainfall. Nat Hazards 42(2):273-285

3. Ashok K, Guan Z, Yamagata T (2001) Impact of the Indian Ocean dipole on the relationship between the Indian monsoon rainfall and ENSO. Geophys Res Lett 28(23):4499-4502

4. Ashok K, Guan Z, Saji NH, Yamagata T (2004) Individual and combined influences of ENSO and the Indian Ocean dipole on the Indian summer monsoon. J Clim 17(16):3141-3155

5. Bala I, Singh OP (2008) Relationship between Indian Ocean dipole mode and summer monsoon. Mausam 59(2):167-172

6. Behera SK, Yamagata T (2003) Influence of the Indian Ocean dipole on the Southern Oscillation. J Meteorol Soc Jpn 81(1):169-177 
7. Bhatla R, Laxmi U, Singh M (2017) Droughts/Floods in Relation to El Nino/La Nina over All-India, East Uttar Pradesh and Some Stations of East Uttar Pradesh. Journal of Climate Change 3(1):27-35

8. Bhatla R, Singh S, Mandal B (2016) Association of Sea Surface Temperature of Different Nino Regions. with Summer Monsoon Rainfall over Indo-Gangetic Plains

9. Bhatla R, Ghosh S, Verma S, Mall RK, Gharde GR (2019) Variability of monsoon over homogeneous regions of India using regional climate model and impact on crop production. Agricultural Research $8(3): 331-346$

10. Bhatla R, Varma P, Verma S, Ghosh S (2020) El Nino/La Nina impact on crop production over different agro-climatic zones of Indo-Gangetic Plain of India. Theoret Appl Climatol 142(1):151-163

11. Box GE, Jenkins GM (1976) Time series analysis, control, and forecasting. San Francisco, CA: Holden Day 3226(3228):10

12. Gadgil S (1995) Climate change and agriculture-an Indian perspective. Curr Sci 69(8):649-659

13. ICAR- Sugarcane Technologies (2015)

14. India Meteorological Department (Ministry of Earth Sciences) Report No. ESSO/IMD/HS/R. F. REPORT/01(2017)/23. Rainfall Statistics of India- 2016

15. Kumar KK, Rajagopalan B, Cane MA (1999) On the weakening relationship between the Indian monsoon and ENSO. Science 284(5423):2156-2159

16. Mohanty S, Satyasai KJ (2015) Feeling the pulse, Indian pulses sector. NABARD Rural Pulse 10:1-4

17. Mooley DA, Parthasarathy B (1983) Indian summer monsoon and El Nino. pure applied geophysics 121(2):339-352

18. Parthasarathy B, Munot AA, Kothawale DR (1988) Regression model for estimation of Indian foodgrain production from summer monsoon rainfall. Agric For Meteorol 42(2-3):167-182

19. Saji NH, Goswami BN, Vinayachandran PN, Yamagata T (1999) A dipole mode in the tropical Indian Ocean. Nature 401(6751):360-363

20. Samanta D, Rajagopalan B, Karnauskas KB, Zhang L, Goodkin NF (2020) La Niña's diminishing fingerprint on the central Indian summer monsoon. Geophysical Research Letters 2020 Jan 28(2):e2019GL086237 47(

21. Benouis K (2017) Phytochemicals and bioactive compounds of pulses and their impact on health. Chem Int 3(3):224-229

22. Shukla SK, Sharma L, Awasthi SK, Pathak AD (2017) Sugarcane in India: Package of practices for different agro-climatic zones. Indian Instituite of Sugarcane Research, Lucknow, pp 1-64

23. Srivastava AK, Rai MK. Sugarcane production: Impact of climate change and its mitigation (2012) Biodiversitas Journal of Biological Diversity 13(4)

24. Upreti P, Singh A (2017) An economic analysis of sugarcane cultivation and its productivity in major sugar producing states of Uttar Pradesh and Maharashtra. Economic Affairs 62(4):711-718

25. Wang B, Xiang B, Li J, Webster PJ, Rajeevan MN, Liu J, Ha KJ (2015) Rethinking Indian monsoon rainfall prediction in the context of recent global warming. Nature communications 6(1):1-9 
26. Webster PJ, Magana VO, Palmer TN, Shukla J, Tomas RA, Yanai MU, Yasunari T (1998) Monsoons: Processes, predictability, and the prospects for prediction. Journal of Geophysical Research: Oceans 103(C7):14451-14510

\section{Figures}

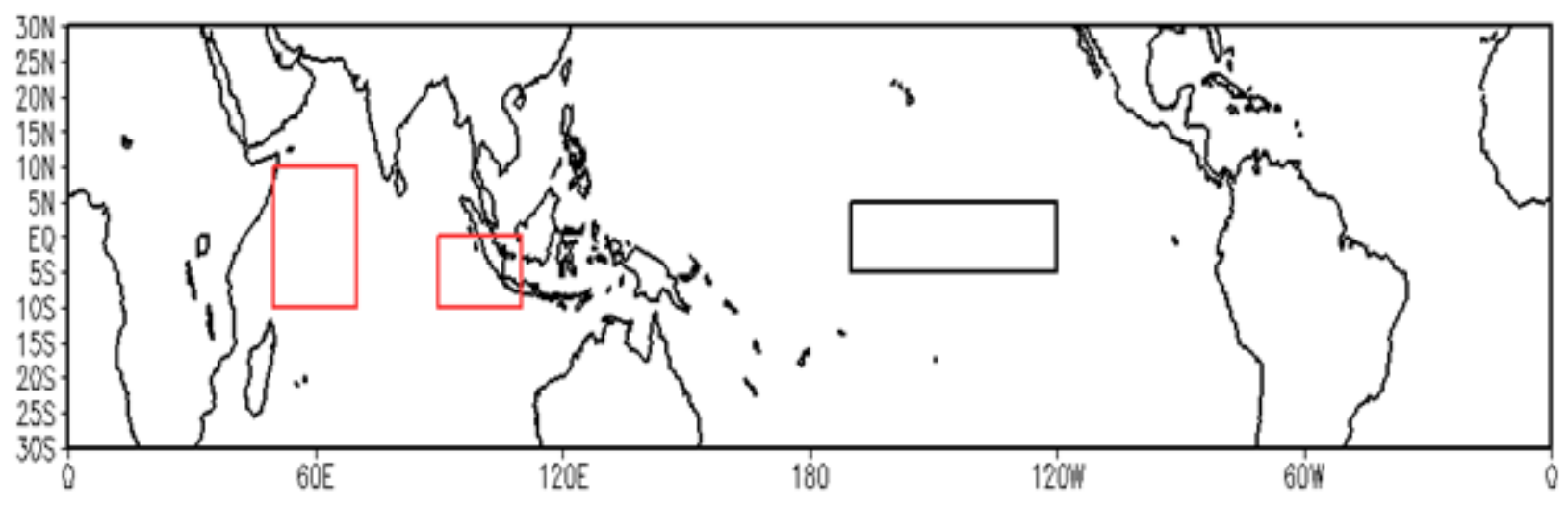

\section{Figure 1}

Region for dipole mode index (DMI) for Indian Ocean (a) western equatorial Indian Ocean (WIO) $\left(50^{\circ} \mathrm{E}-70\right.$ ${ }^{\circ} \mathrm{E}$ and $\left.10^{\circ} \mathrm{S}-10^{\circ} \mathrm{N}\right)(\mathrm{b})$. South eastern equatorial Indian Ocean (SEIO) $\left(90^{\circ} \mathrm{E}-110^{\circ} \mathrm{E}\right.$ and $\left.10^{\circ} \mathrm{S}-0^{\circ} \mathrm{N}\right)$ and the El Nino and La Nina time series are measured by observed SST anomalies over (c). Nino 3.4 region (5oN-5oS, 170oW-120oW) of the Pacific Ocean. 
(a) Central Plateau \& Hills Region

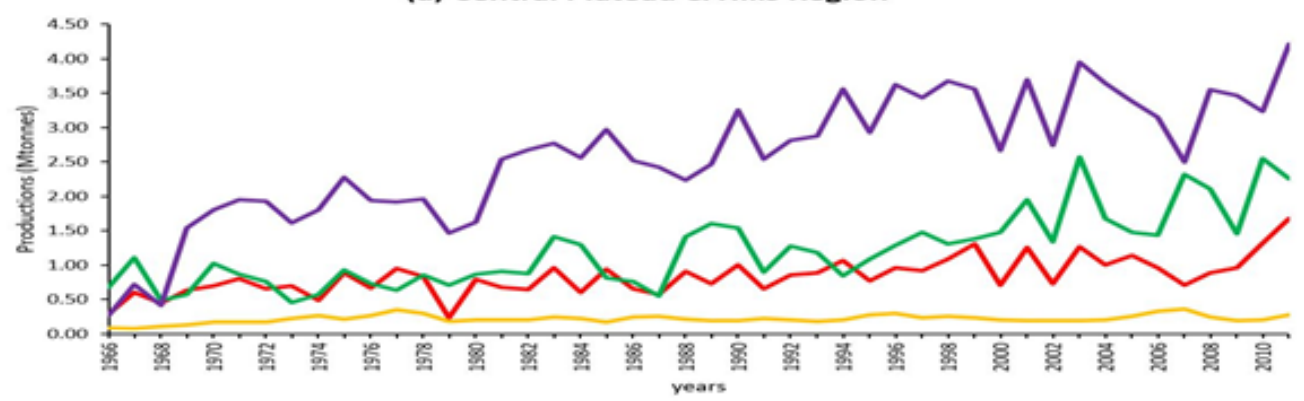

- Rice Maize Pulses - Sugarcane

(b) Western Plateau \& Hills Region

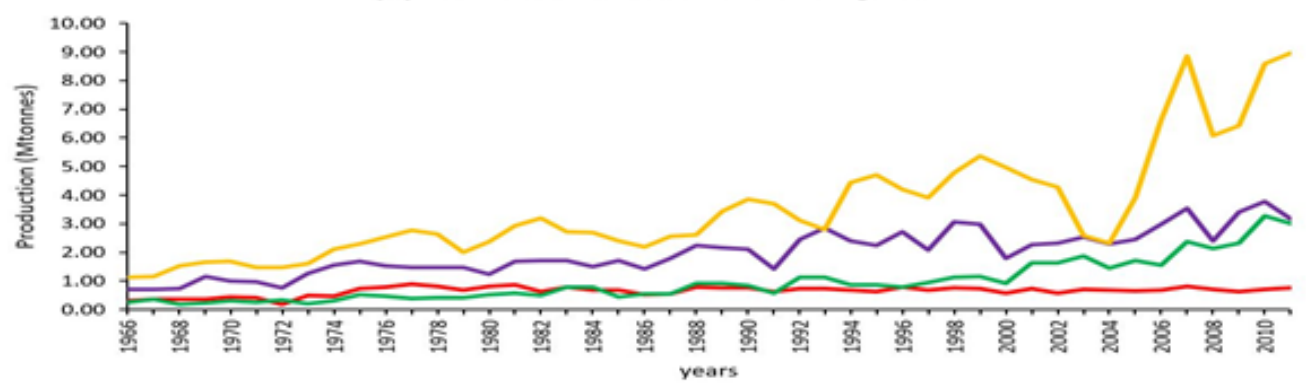

-Rice Maize - Pulses - Sugarcane

(c) Gujarat Plains \& Hills Region

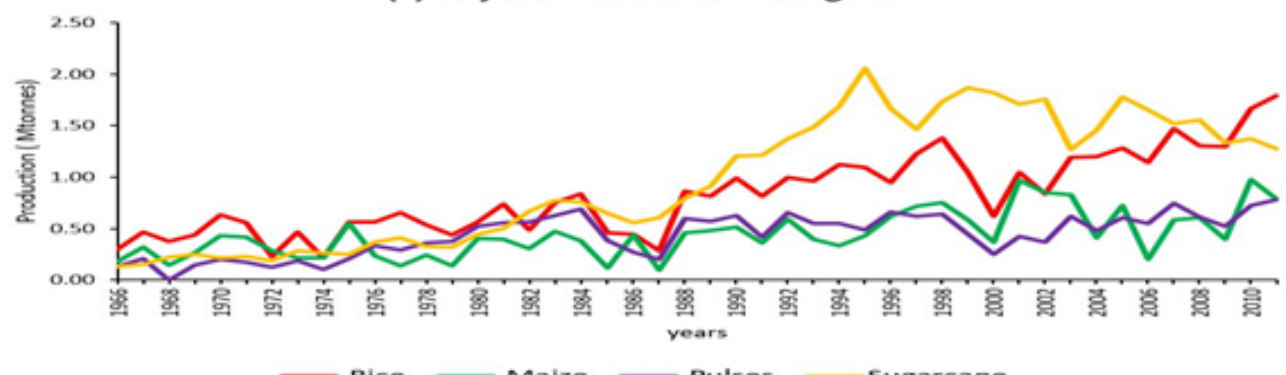

(d) Western Dry Region

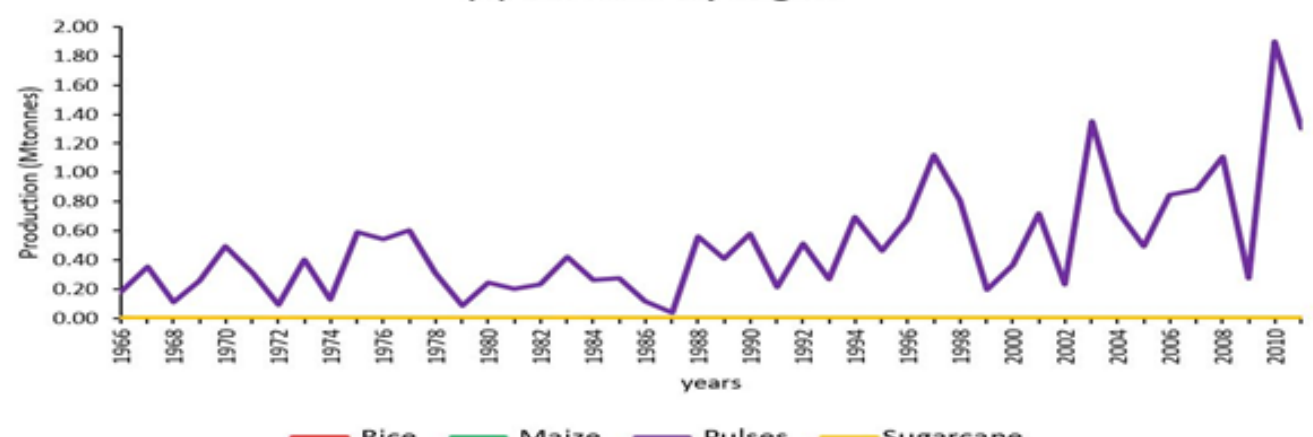

Figure 2

a-d Crop production variation over (a) Central Plateau \& Hills region (b) Western plateau \& Hills region (c) Gujarat plains \& Hills region (d) Western Dry region during 1966-2011. 
CPHR:

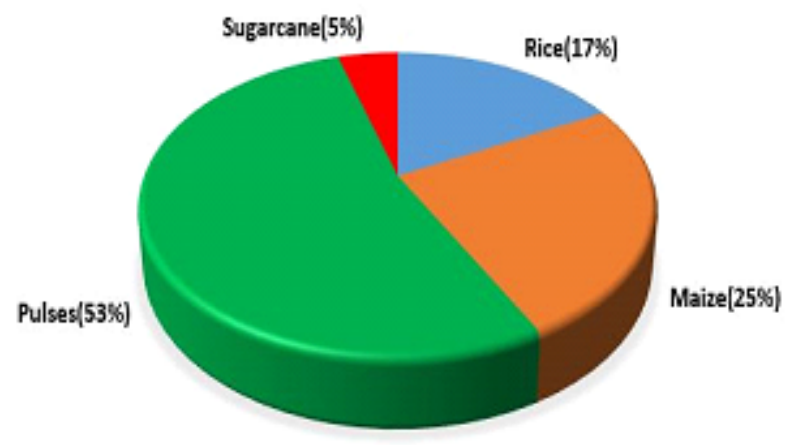

GPHR:

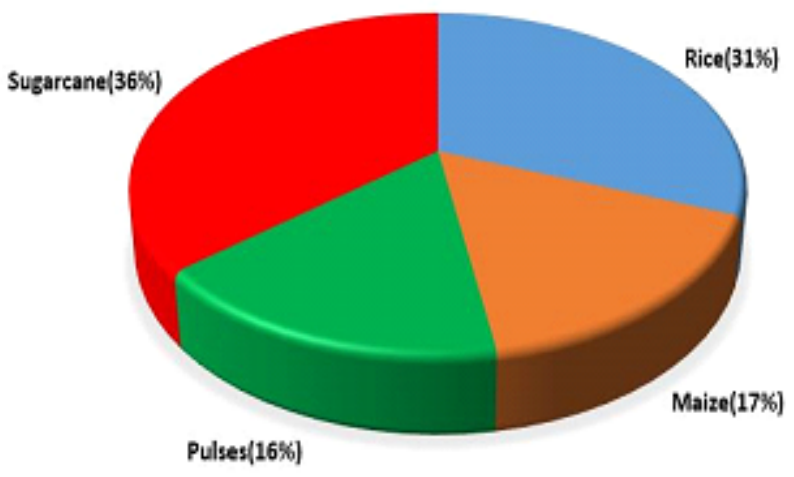

WPHR:

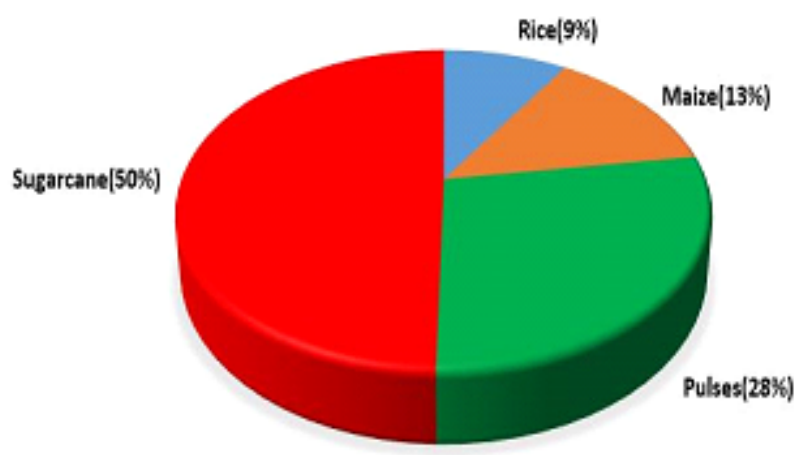

WDR:

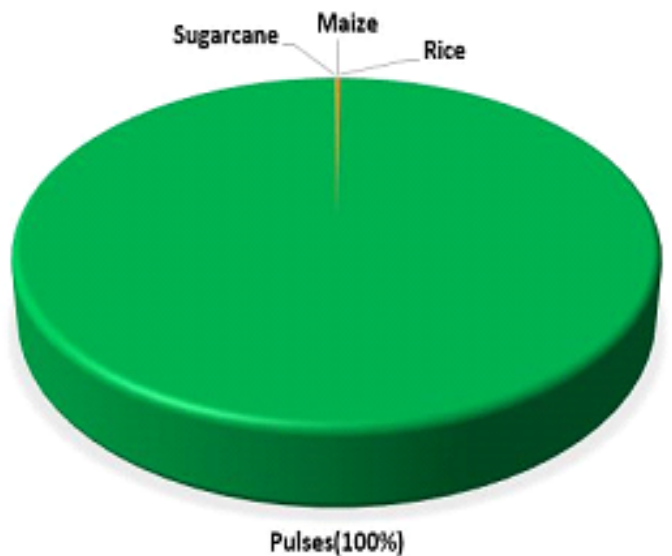

\section{Figure 3}

Percentage contribution of crop productions in four zones during 1966-2011. 

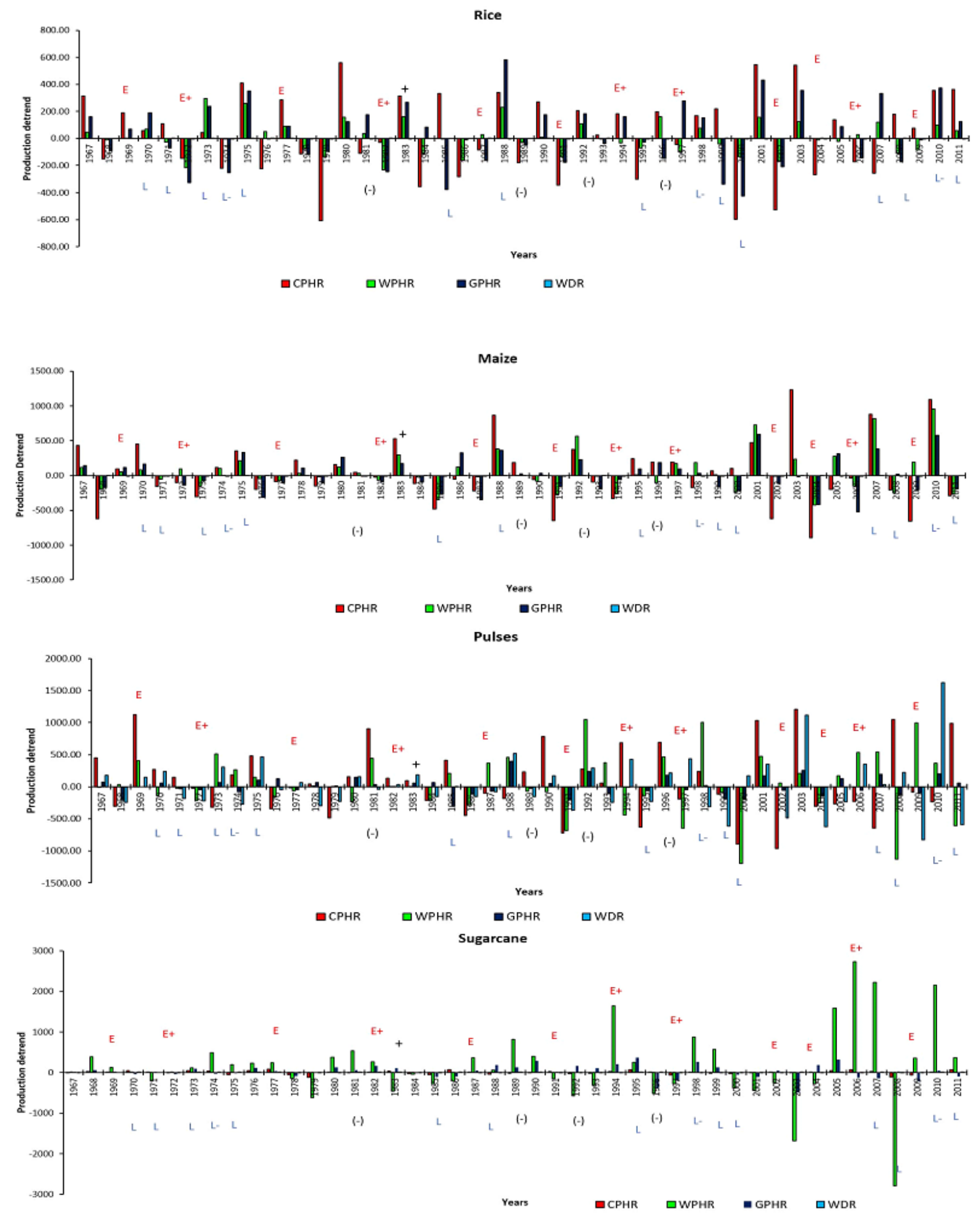

\section{Figure 4}

Time series bar plot representing the detrending of (a) rice (b) maize (c) pulses (d) sugarcane during El Nino, La Nina, positive IOD and negative IOD years. Note: El Nino: E, La Nina: L, El Nino+positive IOD: E+, La Nina + negative IOD: L-, positive IOD: + and negative IOD: (-) 


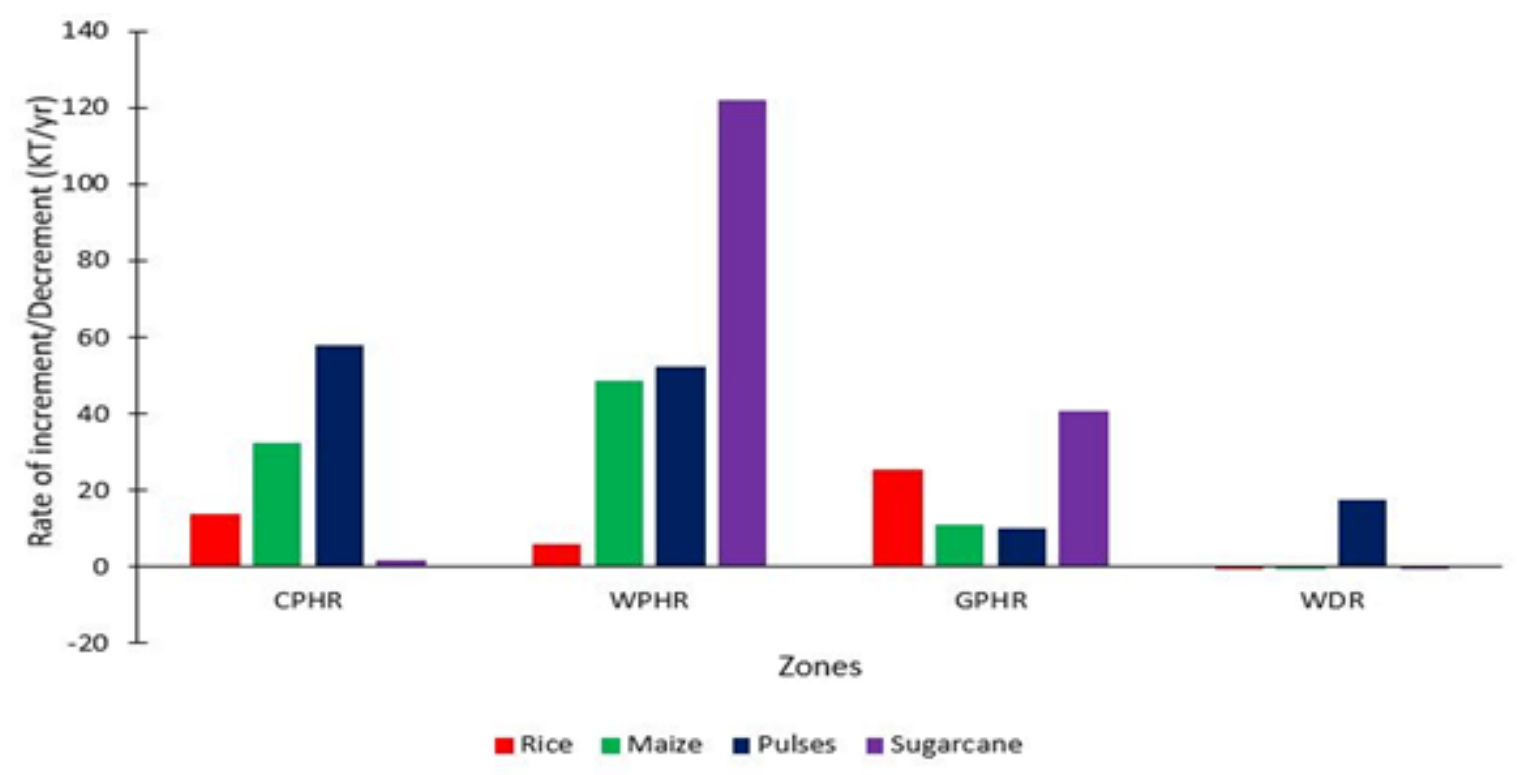

Figure 5

The rate of increment/decrement of crop productions over the entire period of study over four western agro-climatic zones of India. 